\title{
SHOULD ICELAND SEEK EUROPEN UNION AND EURO AREA MEMBERSHIP?
}

\author{
Hilmar Pór Hilmarsson ${ }^{1}$
}

University of Akureyri (Iceland)

\begin{abstract}
Iceland is a small, resource rich country in Europe that is highly dependent on foreign trade. According to the World Bank classifications, Iceland is a high income economy, but with a population of a little bit more than 300 thousand inhabitants, is the smallest economy within the Organization for Economic Co-operation and Development (OECD). Iceland is highly dependent on foreign trade, especially on trade with the European Union, where economic and political integration is evolving and the question about the most feasible level of participation is a future challenge for the country. Iceland is a member of the European Free Trade Association (EFTA), the European Economic Area (EEA) and the Schengen area, and the European Union (EU) candidate country until recently, when its government decided to withdraw its EU membership application. Currently, the EEA agreement ensures Iceland access to the EU common market. The question remains, what is the most feasible arrangement for Iceland's prosperity in the long term? Should it continue to rely on the current arrangement? Should it seek the EU membership in the future and, perhaps, subsequently become part of the Euro Area? What are the possible benefits and disadvantages for Iceland joining the EU and the Euro Area? KEYWORDS: economic integration, small states, Iceland, global crisis, economic policy.
\end{abstract}

JEL CODES: F15, H12, E6

\section{Introduction}

Iceland is a small, resource rich country in Europe that is highly dependent on foreign trade. According to the World Bank classifications, Iceland is a high income economy, but with a population of a little bit more than 300 thousand inhabitants, is the smallest economy within the OECD. Iceland in highly dependent on foreign trade, especially on trade with the European Union, where economic and political integration is evolving and the question about the most feasible and sustainable level of participation in this integration remains a challenge for the country. Iceland is a member of EFTA, EEA and Schengen, and EU candidate country until recently when its government decided to withdrew its application. Should Iceland continue to rely on the current arrangement? Should it seek EU membership in the future and perhaps subsequently become part of the Euro area? What are the possible benefits and disadvantages for Iceland joining the EU and the Euro Area?

Iceland applied for the EU membership in July 2009, and just a year later began accession negotiations. The current cabinet, that took office in May 2013, decided to put the accession negotiations on a complete hold, to dissolve the negotiating structures, and to commission an assessment of the accession process, as well as of developments in the EU (Ministry for Foreign Affairs, 2015). When the accession negotiations were put on hold, 27 out of 33 chapters were opened, out of which 11 have been provisionally closed. 6 chap-

1 Hilmar Pór Hilmarsson - Ph.D. Professor, School of Business and Science, University of Akureyri, Iceland Scientific interests: finance, emergencies economy.

E-mail: hilmar@unak.is

Tel. + 3548498380 
ters were not opened, although negotiating positions were in place for two of them, i.e., the chapter on food safety, veterinary and phytosanitary policy, and the chapter on justice, freedom and security. A negotiating position was not in place for four chapters, i.e., the chapters on agriculture, fisheries, and the free movement of capital, and on the right of establishment and freedom to provide services (Institute of Economic Studies at the University of Iceland, 2014).

Had negotiations resumed, Iceland would have faced contentious issues on fisheries policy which could potentially have derailed the agreement. The chapter on agriculture was also sensitive and challenging. Since those most difficult chapters had never been opened, it is hard to say what changes of the agreement between Iceland and the EU were. Also, if an agreement was reached, the accession treaty would still require ratification by every EU state and be subject to a national referendum in Iceland. Public support for the EU accession measured by opinion polls has fluctuated, but is currently low.

\section{Methodology}

The methodology used in this article is the case study method. Compared to other research methods, a case study enables the researcher to examine the issues involved in greater depth. According to Yin (Yin, 2009: 101-102), six sources of evidence are most commonly used in case studies. They are as follow: documentation, archival records, interviews, direct observations, participant-observation, and physical artefacts. Each of these sources has advantages and disadvantages and, according to Yin, one should "note that no single source has a complete advantage over all the others. In fact, the various sources are highly complementary, and a good case study will therefore want to use as many sources as possible" (Yin, 2009: 101). Among the sources of evidence used for the analysis in this article is secondary data, including analytical reports and scholarly literature with peer-reviewed journal articles and books on the subject. Direct observation also plays a role as the author of this article draws on his own experience and observations while living in Iceland and following the domestic dialogue on the EU accession. The author also draws on his experience as a Special Advisor to the Minister for Foreign Affairs in Iceland from 1995 to 1999 and as a staff member of the World Bank in Latvia from 1999 to 2003, just before Latvia, another small country, became an EU member state. Preference is given to using well documented evidence that is publicly available and listed in the references. The author also conducted interviews and collected information at the European Central Bank in June 2015 and at the European Commission and EFTA in July 2015. This case study does not present results that can be evaluated on the basis of statistical significance and one should be careful about generalizing or projecting the findings of one case study onto another case or situation. However, some lessons from the study could have wider relevance than for Iceland only. This is especially true for small, open, resource rich economies, dependent on the access to a large common market, using its own currency, and with limited institutional capacity to respond to external shocks and pressures in the globalization era.

The organization of the article is as follows: (i) some theoretical considerations regarding gains from trade, economic integration with reflection on small states; (ii) a brief literature survey on the Icelandic economy and its changing structure; (iii) the global crisis and recent economic performance; (iv) the possible benefits and disadvantages of Iceland joining the EU and subsequently the Euro area; (v) discussion about the consequence of small economic size experienced by Iceland, and, finally, conclusions.

\section{Theoretical considerations}

Classical economic theory documents gains from international trade, demonstrating that nations can improve their welfare by engaging in cross-border trade with other nations. To this day, this is one of the fundamental principles underlying arguments for all countries to strive for expanding and promoting free world trade (e.g., Czinkota et al., 2009). The efficiencies derived from economics of scale are also a key argument 
for economic integration ${ }^{2}$ and the creation of a common market where all participating countries can benefit from it. The level of economic integration varies. Listing from the least to the most integrative, they are as follow: the free trade area, the customs union, the common market and, finally, the economic union. EFTA, where Iceland is a member since 1970 (see Table 1), is a free trade area and represents the loosest form of economic integration where all barriers for trade among member countries are removed.

Table 1. European Free Trade Association (EFTA) $)^{3}$ membership through the years

\begin{tabular}{|l|l|}
\hline 1960 & Austria, Denmark, Norway, Portugal, Sweden, Switzerland and the United Kingdom establish EFTA \\
\hline 1970 & Iceland becomes a member of EFTA \\
\hline 1972 & Denmark and the United Kingdom leave EFTA to join the European Economic Community (EEC) \\
\hline 1985 & Portugal leaves EFTA to become a member of the European Economic Community (EEC) \\
\hline 1986 & Finland becomes a full member of EFTA \\
\hline 1991 & Liechtenstein becomes a member of EFTA \\
\hline 1995 & Austria, Finland and Sweden leave EFTA to join the European Union (EU) \\
\hline
\end{tabular}

Source: EFTA, 2014.

However, it does not have a common trade policy, such as a common external tariff, with respect to nonmembers, like the customs union does. EFTA has three core tasks. The first is the liberalization of intra-EFTA trade. The second - the EFTA States have built networks of preferential trade relations in the world, currently consisting of 25 free trade agreements (FTAs) with 35 partners. Finally, three of the four EFTA States - Iceland, Liechtenstein and Norway - are parties to the EEA Agreement, ${ }^{4}$ which ensures their participation in the Internal Market of the European Union ${ }^{5}$ (EFTA, 2014). As Table 1 shows, EFTA has lost most of its members who chose closer economic integration by joining the EU.

The EU is moving towards an Economic Union. This involves not only abolition of tariff and quotas among members (like in the case of a free trade area such as EFTA), but also the common tariff and quota system, abolition of restrictions of factor movements, as well as harmonization and unification of economic policies and institutions. The formation of an economic union requires nations to surrender a large measure of their national sovereignty to supranational authorities in the union wide institutions.

The level of integration varies among countries within the EU, as 19 out of 28 member states have adopted the euro $(€)$ as their common currency and the sole legal tender (see Figure 1). The formation of a common currency area can bring benefits to the members of the currency union, particularly if there is a high degree of international trade among them (i.e., a high level of trade integration). This is primarily because of the reductions in transaction costs in trade and the reduction in the exchange rate uncertainty. However, there

2 In addition to economic benefits of economic integration there can also be important political and security concerns that drive the integration process.

3 The European Free Trade Association is an intergovernmental organization set up for the promotion of free trade and economic integration to the benefit of its Member States (today: Iceland, Liechtenstein, Norway and Switzerland). The Association is responsible for the management of: the EFTA Convention, which forms the legal basis of the organization and governs free trade relations between the EFTA States; the EFTA's worldwide network of free trade and partnership agreements; and the Agreement on the European Economic Area, which extends the Internal Market of the European Union to three of the four EFTA States (Iceland, Liechtenstein and Norway) (EFTA, 2014).

4 The EEA Agreement does not include the following EU policies: Common Agriculture and Fisheries Policies; Customs Union; Common Trade Policy; Common Foreign and Security Policy; Justice and Home Affairs (the EFTA States are part of the Schengen area); Economic and Monetary Union (EMU).

5 The EEA EFTA States do not have the right to participate in the political decision making within the EU institutions. The EEA Agreement does, however, provide the EEA EFTA State experts with the opportunity to contribute to the shaping of EU legislation (EFTA, 2014). 
are also costs of joining a currency union, namely: the loss of independent monetary policy and the loss of the exchange rate as a means of macroeconomic adjustment.

In addition to economic theories on the gains from trade and economies of scale, as well as theories on economics of integrations, including the common currency area, there are also theories on the behaviour of small states within multilateral arrangements. Small states, as well as large states, have a choice to engage in bilateral negotiations and/or multilateral arrangements addressing issues that cannot be resolved only within their borders. Bilateral negotiations are carried out between two nations focusing only on their interests. On the other hand, multilateralism is the international governance of the many, and in the case of the EU - 28 member states large and small among them.

Multilateral negotiations open up the possibility for small states, along with larger ones, to participate in international decision making. According to Thorhallsson, a leading scholar on small states, the literature on small states' issues generally claims that it is beneficial for small states to concentrate on multilateral relations within international organizations (Thorhallsson, 2005). When discussing multilateralism Kahler states that "Smaller, weaker states were believed to be disadvantaged by bilateralism..." and "[i]n their formal institutional design at least, most postwar multilateral institutions incorporated a larger role in decision making for states that were not great powers and could not aspire to be" (Kahler, 1992: 681). When discussing small states as aid donors, Hoadley predicts high levels of participation by small states in multilateral agencies (Hoadley, 1980: 129). This would apply to the United Nations (UN) as well as multilateral development banks. More recently, Evans and Newnham argue that small states are said to have limited involvement in the world affairs, favour intergovernmental organizations, are advocates of international law, shy, away from the use of military force and in general have limited, mostly regional, foreign policy priorities (Evans and Newnham, 1998: 500-501). Finally, Maass states that "[m]embership and participation in international governmental organizations is not only a frequent priority of small states, but it has also been discussed as an indicator of independence, and as such as a secondary definitional requirement for small states in particular" (Maass, 2009: 69). A group of small states can also be influential as Ingebritsen argues, when discussing Scandinavian countries, that "these states exercise collective authority beyond their borders that exceed their military or economic might" (Ingebritsen, 2006: 1). She also argues that Scandinavians are likely to be found in groups that seek to strengthen international institutions. Scandinavian countries are indeed active participants in the UN and in multilateral development banks, and among them Denmark, Finland and Sweden are the EU members and give high priority to active participation within the EU institutional systems.

Keohane suggests that we focus on the systemic role that state leaders see their countries playing. This is critical to understand the impact countries can have on the international community. Keohane distinguishes the following categories of states: system-determining, when a state plays a critical role in shaping the international system; system-influencing are states that cannot expect to individually dominate the international system but may be able to influence it through unilateral or multilateral action; system-affecting states are those that cannot affect the international system if acting alone but can exert significant impact on the system if working through small groups or alliances or through universal or regional international organizations; and, finally, system-ineffectual states are those that can do little to influence the system-wide forces that affect them, except in groups which are so large that each state has minimal influence (Keohane, 1969: 295-296).

How can this categorization contribute to the behaviour of small states in international organizations? As Keohane observes, “.... major function of international organizations - perceived by many small and middle powers - is to allow these states acting collectively to help shape developing international attitudes, dogmas and codes of proper behavior" (Keohane, 1969: 297). For example, Iceland, acting alone or in partnership with a very large number of other countries, would have little impact and would be classified as systemineffectual. Iceland could do little in most cases to influence system-wide forces. However, situations can exist, including international development cooperation, where small countries that work in partnership, such as the Nordic-Baltic group, could become system-affecting (see, e.g., Hilmarsson, 2011). 
In the past Iceland cooperated multilaterally with the Nordic countries and parliamentarians from those countries met regularly in joint sessions. During the Cold War Iceland had strong bilateral relationship with the USA, a system-determining country, including a bilateral defence agreement. The political ties between the two countries could be critical in resolving disputes between Iceland and other countries, most notably in the dispute with the UK over fisheries territories. In the post-cold war this relationship becomes weaker and does not provide the shelter it did in the past. Unlike Denmark, Finland, Sweden and the Baltic States, Iceland, an EEA EFTA country (with Norway), in not an EU member and is not sheltered by the EU institutions (see Figure 1). There is a possibility, at least in theory, that the Nordic-Baltic countries could become system-affecting states within the EU if they cooperate as a group.

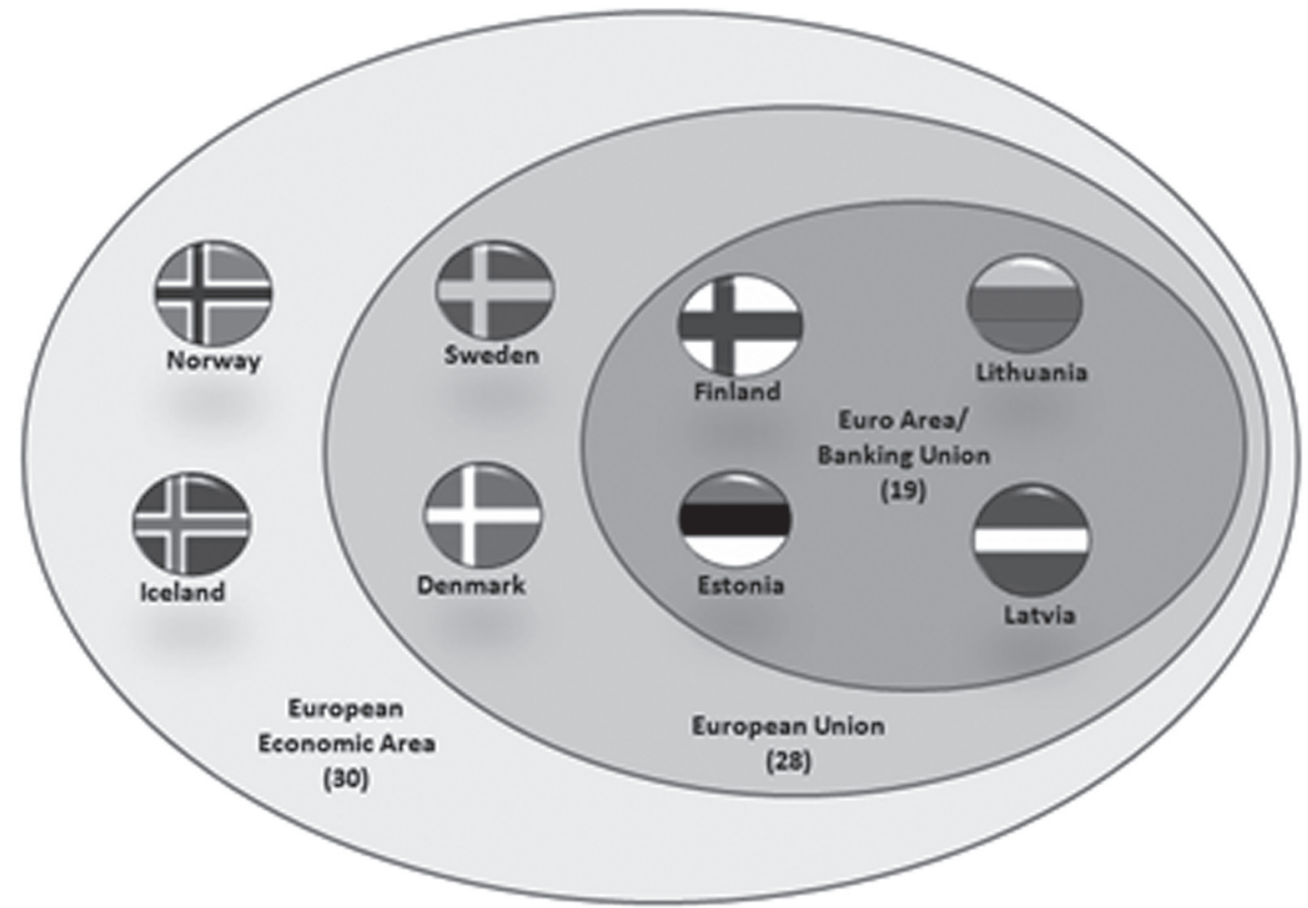

Figure 1. The Nordic and the Baltic States, all small countries, have chosen different levels of European integration. Norway and Iceland have the lowest level of integration but the Baltic States and Finland have the highest level of integration.

Source: constructed by the author.

Although the three EEA EFTA states do not have the right to participate directly in the political decision making within the EU institutions, the EEA Agreement provide their experts with the opportunity to contribute to the shaping of EU legislation at the preparatory stage. This is done via participation in the European Commission's (EC) expert groups and committees. These groups advise the EC on the drafting of new laws, which the EU Council of Ministers and the European Parliament subsequently adopt. The participation of EEA EFTA experts and representatives in over 500 of these committees and groups is a valuable opportunity to acquire information and contribute to new legislative proposals at the earliest stages of policy formation (EFTA, 2014). This, however, means that the EEA EFTA states need to allocate sufficient human resources to take full advantage of this opportunity and this has been a challenge for Iceland. The EEA Agreement is supported with its own institutions and a formal cooperative mechanism vis-a-vis the EU institutions. Thus, the mechanism for decision shaping has been formalised and if used wisely can enable the EEA EFTA states become system-affecting in some cases (see Figure 2). 


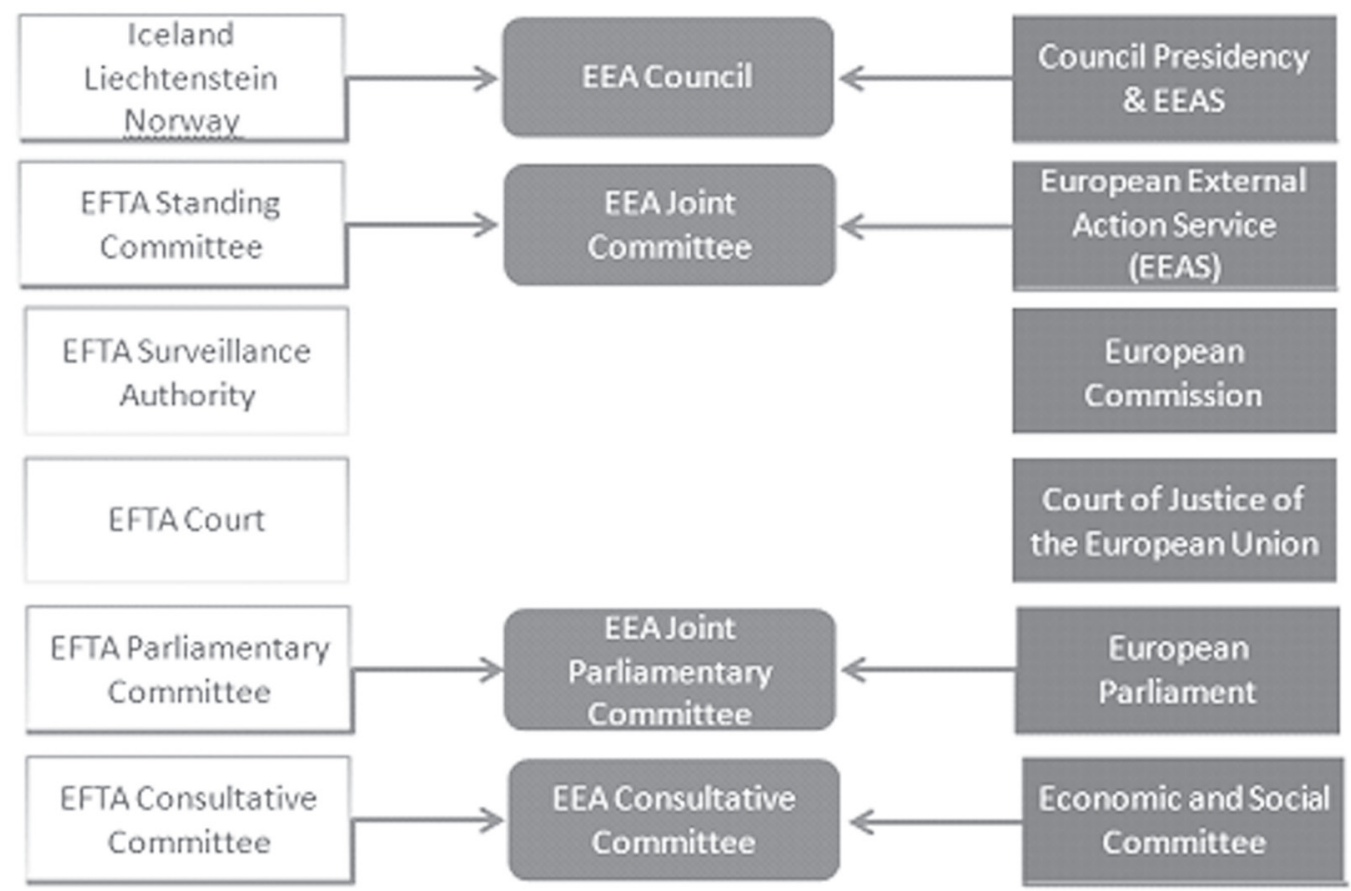

Figure 2. Decision shaping under the Two-Pillar Structure under the EEA Agreement. The EEA Agreement established EEA EFTA bodies to match those on the EU side

Source: EFTA, 2014.

\section{The Icelandic economy and its changing structure}

As stated above, Iceland is an open economy that participates in major European cooperative projects, including EFTA, EEA, Schengen, as well as NATO. Moreover, it is an active participant in cooperation within the Nordic Region. The Icelandic economy is the smallest within the OECD. Its size is about $0.1 \%$ of the US economy, $4 \%$ of the Danish economy, and $25 \%$ of the economy of Luxembourg, while it is more than $50 \%$ larger than the economy of Malta (CBI, 2014).

Iceland is classified by the World Bank as a high income economy but the small size of its economy reflects the country's small population which was 329.100 on January 1, 2015. Iceland is considered to be a Nordic country and has the characteristics of a Nordic welfare state. For instance, Gross National Income (GNI) per capita measured in terms of Purchasing Power Parities (PPP), according to the World Bank data, amounted to nearly 39 thousand US dollars in 2013, the twenty-second highest in the world and the thirteenth highest among the OECD countries. Iceland's GNI per capita is lower than that in Denmark, Norway, and Sweden but marginally higher than in Finland and slightly above the EU average (CIB, 2014).

Historically, Iceland's prosperity to a large extent has been built on its comparative advantage in the marine and energy sectors (hydro and geothermal power), with investment and services as the main drivers of growth. Tourism has soared over the past few years and has become one of the main engines of export growth. In fact, tourism has established itself as the third pillar of the Icelandic economy (in addition to the fisheries and energy sectors), and as a result, Iceland's economy has become better diversified. Currently, the largest Iceland's trading partner countries are the Netherlands, Germany, Norway, the US, and the UK (CIB, 2014). The Euro area constitutes the largest trading area. 
Table 2. Iceland: General Information

\begin{tabular}{|l|l|}
\hline Name & Iceland \\
\hline Government & Constitutional Republic \\
\hline Head of State & President \\
\hline Head of Government & Prime Minister \\
\hline Official Language & Icelandic \\
\hline Capital & Reykjavík \\
\hline Area & 103000 Km2 \\
\hline Population & 329.100 (January 1, 2015) \\
\hline Population Density & 3.1 \\
\hline Currency & Icelandic króna (ISK) \\
\hline
\end{tabular}

Sources: official government websites.

Over the past 10 years, the Icelandic labour market has had a participation rate consistently above $85 \%$, one of the highest among the OECD countries. In 2013, female participation was one of the highest in the OECD countries, with women accounting for $48 \%$ of the labour force. Participation rates among the young and the elderly have also been quite high (CIB, 2014). Similarly, unemployment has been low too compared to EU member states and currently is about $4 \%$.

Though Iceland participates in European integration via the EFTA and the EEA agreement, its history shows that the country is sceptical about the benefits deriving from participation in international organizations and has not built a strong institutional capacity to cooperate on a multilateral basis. However, this is not the only true reason if one considers the EU membership scepticism. Besides, Iceland has not sought membership in as many institutions where other Nordic countries actively participate in, including the regional development banks ${ }^{6}$. Therefore, Iceland tends to favour more informal multilateral arrangements, bilateralism and sometimes unilateralism during times of crisis (e.g., Hilmarsson, 2014; Dinh and Hilmarsson, 2012). Then again this contradicts the small states theories discussed above.

\section{The global financial crisis and recent post crisis economic performance}

Iceland was among the hardest hit economies during the global economic and financial crisis that erupted in 2008. Prior to the crisis Iceland had experienced strong economic growth and unprecedented expansion in cross-border investments, especially in the financial sector (e.g., Hilmarsson, 2013a and 2013b). According to the IMF, the consolidated assets of the three main Icelandic banks increased from 100\% of GDP in 2004 to $923 \%$ at the end of 2007 , reflecting expansion overseas. Therefore, by the end of 2007 , almost $50 \%$ of the three largest banks' assets were held abroad (IMF, 2008: 11). The banks had been privatized several years before the crisis with a light touch regulation and weak supervision in the spirit of laissez-faire policies. Before the crisis the government of Iceland publicly announced its ambition to turn Iceland into an international financial centre.

However, the three largest banks, representing about $85 \%$ of the banking system, all collapsed in just a few days in October 2008. The whole economy was severely affected by this economic turbulence. As a result, the Icelandic krona sharply depreciated, GDP fell, and inflation as well as unemployment rose, and the government ran large fiscal deficits in the aftermath of the crisis (see Table 3). Unlike some EU member states, where the fixed exchange rate regime and austerity programs were implemented, the Icelandic government sought to protect the welfare system resulting in large fiscal deficit which hoped to be only temporary. Sharp depreciation of the local currency was expected to boost exports and GDP growth like it happened, for example, in Finland and Sweden in the early 1990s (e.g., Hilmarsson, 2014).

6 Those are the African Development Bank, the Asian Development Bank, and the Inter-American Development Bank. 
Table 3. Iceland: selected economic indicators 2007 to 2014 (Percent change)

\begin{tabular}{|c|c|c|c|c|c|c|c|c|}
\hline & 2007 & 2008 & 2009 & 2010 & 2011 & 2012 & 2013 & 2014 \\
\hline Gross domestic product $1 /$ & 6.0 & 1.3 & -6.8 & -4.0 & 2.1 & 1.1 & 3.5 & 2.0 \\
\hline Unemployment rate $2 /$ & 1.0 & 1.6 & 8.0 & 8.1 & 7.1 & 6.0 & 5.4 & 5.0 \\
\hline Consumer price index (average) & 5.0 & 12.4 & 12.0 & 5.4 & 4.0 & 5.2 & 3.9 & 2.0 \\
\hline \multicolumn{9}{|c|}{ (Percent of GDP) } \\
\hline General government balance 3/ & 5.4 & -0.5 & -8.6 & -6.4 & -5.6 & -3.7 & -1.7 & -0.1 \\
\hline Current account balance & -15.7 & -28.4 & -11.8 & -8.4 & -5.2 & -4.2 & 5.5 & 3.7 \\
\hline \multicolumn{9}{|l|}{$\begin{array}{l}\text { 1/ Constant prices } \\
\text { 2/ In percent of labour force } \\
\text { 3/ National account basis }\end{array}$} \\
\hline
\end{tabular}

Source: IMF 2010, 2012, 2015a, 2015b and the World Economic Outlook Database

Nevertheless, after almost seven years since the crisis hit, Iceland has reached a relatively strong macroeconomic position with good growth prospects (see Tables 3 and 4). Fiscal and external balances are now in surplus and economic activity, according to the IMF, will surpass its pre-crisis peak in 2015. According to the Central Bank of Iceland, the post-crisis contraction in GDP has reversed in full (CBI, 2015). Public debt is on a downward sustainable path. Moreover, unemployment continues to trend down, now reaching 4\%. Though growth slowed last year but it is expected to rise up to around 3\% over 2015-2017, supported by the robust domestic demand and tourism. Consumption has been boosted by the household debt relief and, together with net trade, have benefited from favourable commodity prices (IMF, 2015). The IMF projects GDP growth to be 3.2 in 2016 (see Table 4).

However, there are increasing concerns that economic stability may be threatened with the current demand of salary increases well beyond the current growth rate. Large salary increase could undermine economic recovery and the competitive position of the economy, and lead to a reduction in employment (CIB, 2015). In addition, the government has been criticized for granting debt relief to households that to a large extent could have serviced their debt without such relief. This effort is also seen as discriminatory against those households who chose to rent their housing and socially vulnerable families who may be in greater need of assistance than homeowners. Amid low unemployment, wage pressures are building. There is a risk that hardly earned post-crisis macro stability may be lost if increases in salaries go out of control, followed by rising inflation, like it has repeatedly happened in Iceland over the decades.

Table 4. Iceland: selected economic indicators 2014 to 2016 Estimate and Projections (Percent change)

\begin{tabular}{|c|c|c|c|}
\hline & 2014 & 2015 & $2016 \mathrm{p}$ \\
\hline Gross domestic product 1/ & 2.0 & 4.0 & 3.2 \\
\hline Unemployment rate $2 /$ & 5.0 & 4.0 & 4.0 \\
\hline Consumer price index (average) & 2.0 & 1.6 & 2.1 \\
\hline \multicolumn{4}{|c|}{ (Percent of GDP) } \\
\hline General government balance 3/ & -0.1 & 0.7 & 0.1 \\
\hline Current account balance & 3.7 & 4.2 & 4.7 \\
\hline $\begin{array}{l}\text { 1/ Constant prices } \\
\text { 2/ In percent of labour force } \\
\text { 3/ National account basis } \\
\text { p/ Projections }\end{array}$ & & & \\
\hline
\end{tabular}

Source: IMF 2015a, 2015b and the World Economic Outlook Database

According to the IMF, "The outlook for growth is positive. The economy will grow at around 3 percent during 2015-2017 under baseline assumptions of large energy-intensive investment projects, robust growth in private consumption boosted by household debt relief, and further expansion of the tourism sector. Terms of trade, consumption, and growth in 2015 will benefit from a sharp decline in oil prices. Investment will be funded by FDI, retained earnings, and, increasingly over time, borrowing. Inflation is expected to stay below 
1 percent this year and rise gradually to target by the end of 2016, as the effects from imported deflation and currency appreciation dissipate and pressures from wages and a closing output gap mount" (IMF, 2015: 7). The Central Bank of Iceland projects stronger GDP growth rate than the IMF at 3.5\% in 2016 (CIB, 2015).

The Icelandic economy is still vulnerable, but better diversification, including in sectors generating foreign exchange, helps maintain stability. In its discussions with the IMF the government has expressed deep concerns about the upcoming collective wage bargaining round and implications for stability. Price stability is still within the target of the Central Bank of Iceland and is helped by disinflation in key trading partners, particularly the euro area, a slump in oil prices, and an appreciating currency in the context of high exchange rate pass-through. However, this can change quickly as it was discussed above.

Iceland has been under capital controls for almost seven years. Strong macroeconomic fundamentals and the healthy financial sector is among the keys for successful capital account liberalization. As the IMF has recently stated, "Liberalization of the capital account under a revised strategy could pick up pace, boosting confidence and private investment and raising long-term growth - but missteps could lead to a disorderly unwinding or even prolonged controls. Wage demands in the upcoming round of collective bargaining could lead to further strikes, and resulting wage hikes could increase inflation and weaken competitiveness" (IMF, 2015b). Thus, the question remains: Have Icelanders learned anything from the past or will the economy return to the boom and bust scenario yet again as it have been for decades and was most recently during the 2008 crisis?

\section{Possible benefits and disadvantages of Iceland joining the European Union} and the Euro Area

\subsection{Benefits}

Among the key benefits of joining the EU is the access to the common market. Iceland has already enjoyed this benefit via the EEA agreement, i.e., free flow of goods, services, capital and people across national borders. Iceland was also able to avoid the collapse of the Nordic Passport Union due to its membership in Schengen. Yet it has enjoyed many of the benefits (some would say most) of economic integration without EU membership and can thus to some degree both eat the cake and keep it.

In the future there could be questions about the EEA sustainability. Will the EU still respect the EEA agreement in the coming decades or is it only a temporary arrangement? Here partnership with Norway in the EEA EFTA is critical. If Norway became a member of the EU, Iceland would hardly have the capacity to engage in negotiations with the EU alone with Lichtenstein. Being a member of the EU Iceland could be more confident that the benefits of the access to the single market would be in place in the longer term. The membership would also ensure regular consultations and participation in the EU decision making instead of continuing instructions via email from Brussels. Regular consultations could help a small country with limited institutional capacity to increase professionalism.

Moreover, EU membership could possibly shield Iceland during times of crisis, economically and in terms of security. There is greater need for the outside support/shield given weaker ties with the USA during the post-cold war. Closer cooperation with EU member states and support from EU institutions could contribute to stability, as Iceland has a history of economic boom and bust.

However, the risks associated with a small population, including close ties among individuals that can result in corruption and rent seeking, could be reduced. During the 2008 crisis there was certain loss of confidence in the Icelandic political and institutional system. General elections took place in the spring of 2009 and the EU application followed three months later. This is hardly a coincidence.

EU membership would mean that Iceland after two years of membership could possibly join the Euro Area. Currently, Iceland does not participate in the EU's monetary system, therefore, cannot adopt the euro and also remain in good standing with the EU. The adoption of the euro unilaterally does not seem like a viable option (e.g., Buiter, 2000 and ECB, 2008). The exchange rate of the local currency fluctuated greatly 
in the past and during the 2008 capital controls, which were introduced as a temporary measure. Capital controls are still in place, almost seven years after the crisis, but the government has recently announced plans to abolish those controls.

\subsection{Disadvantages}

In Iceland there is a concern about the EU's Common Fisheries Policy (CFP) and Common Agriculture Policy (CAP). These potentially most difficult chapters, on the CAP and CFP, were not opened during accession negotiations so it is impossible to say if a compromise could have been reached and at what cost for Iceland. Furthermore, the nation is divided in its support. The EU membership has stronger support by employers outside the fishing industry and agriculture. The political importance of agriculture sector in Iceland is much greater than its economic contribution would suggest. By staying out of the EU Iceland avoids implementing the CFP and CAP of the EU.

If Iceland becomes a member of the EU, its influence within such a large institutional structure would be minimal. In fact, given its small size influence via membership would be a token benefit only. Iceland would also have a tiny weight in the Euro Area economy should it adopt the euro. A common currency would have limited Iceland's possibilities to respond to the 2008 crisis when depreciation of the króna played an important role in bringing about the adjustment of Iceland's trade deficit.

Small states have experienced difficulties in dealing with the larger EU states and EU institutions and this became clear during the 2008 crisis. Large EU states, supported by EU institutions, do not hesitate to use strong arm tactics against small states. An example of this is the EU's handling of the crisis in Ireland and Latvia. The UK and the Netherlands, supported by the EU also used strong arm tactics against Iceland during the so called Icesave dispute. The Icesave dispute had negative effects on the sentiments in Iceland towards the EU and the European nations, including the Nordic countries (who supported the Netherlands and the UK in its dispute with Iceland during the crisis).

When discussing Iceland's response to the crisis the European Central Bank comments as follows: "When Iceland's policy response in the wake of the crisis is compared with that of other affected countries, there are two measures that stand out most. First, Iceland introduced capital controls to protect itself from the worst repercussions of the sudden reversal of capital flows that it faced at the end of 2008, a strategy that has possibly aided its subsequent recovery. However, as time goes by, evidence is mounting regarding the distortive and often detrimental effects that these restrictions are having on the decision-making of economic agents and the difficulties that Iceland's authorities face in decisively reducing the substantial stock of krónur that continues to be held offshore and returning to a fully liberalized capital account in the near future. Second, Iceland decided not to nationalize the debts of its oversized banking sector, instead opting to inflict losses on its financial institutions' creditors and foreign depositors. Although this saved the government from assuming liabilities that would potentially have been beyond its debt-servicing capacity, it also opened the door to a series of legal challenges (with final decisions still pending in some instances), thereby introducing a significant degree of uncertainty for authorities, businesses, foreign investors and the general public" (ECB 2012: 97).

However, the talks about "a series of legal challenges" and "a significant degree of uncertainty for authorities" could be viewed as comment or advice from the EU, but one also could view this comment as a threat. A small nation that does not yield to the EU and its larger member states will sooner or later suffer the consequences. To give an illustration, the case of Latvia and Ireland comes into mind. Such comments or threats are not likely to increase confidence in the EU in Iceland.

Eventually, the Icesave dispute went to the EFTA Court ${ }^{7}$ were Iceland came out as the winning party. After receiving the court ruling the Icelandic Ministry for Foreign Affairs commented as follows: "The

7 The EFTA Court, based in Luxembourg, corresponds to the Court of Justice of the European Union in matters relating to the EEA EFTA States. The Court deals with infringement actions brought by ESA against an EEA EFTA State with regard to the implementation, application or interpretation of an EEA rule. The Court also handles the 
EFTA Court ruling on Icesave rejected all claims by the EFTA Surveillance Authority that Iceland should be declared in breach of the EEA Agreement. The Court rejected the claim that Iceland has breached the Deposit Guarantee Directive or has discriminated against depositors contrary to EEA law. It is a considerable satisfaction that Iceland's defence has won the day in the Icesave case; the EFTA Court ruling brings to a close an important stage in a long saga" (Ministry for Foreign Affairs, 2013). Thus, had Iceland yielded to EU demands, this could have brought its debts to an unsustainable level.

Several scholars have commented on the damaging effect that the Icesave dispute had on Iceland's sentiments towards the EU. Professor Gylfi Magnússon, who served as a Minister for Economic Affairs in the government coalition after the crisis hit, commented as follows: "The governments of Britain and the Netherlands have not directly linked the dispute about Icesave to Iceland's application for membership of the EU, but individual politicians in these countries, especially the Netherlands, have done so, e.g., encouraged their countries to oppose the progression of the application unless Iceland accedes to their demands. Understandably, such threats are very hard for Icelanders to swallow and they have undermined support for EU membership in Iceland. The Icesave dispute has undoubtedly had a very negative effect on many Icelanders' attitudes to other European nations and the EU and has fuelled nationalism and isolationism" (Magnusson, 2010). Thorhallsson and Rebhan comment as follows: “...while Iceland struggled to obtain assistance from the International Monetary Fund (IMF), Britain and the Netherlands allegedly blocked such assistance on a number of occasions, with the formal and informal approval of other European states" (Thorhallsson and Rebhan, 2011).

It is hard to be impressed with the EU's handling of its post crisis problems. Currently, one can say that the EU is faced with three crises: (i) a financial crisis, including a banking and a debt crisis; (ii) an economic policy crisis, including austerity programs, cutting welfare programs and increasing taxes; and (iii) a political crisis, where market forces compete against democracy. The post crisis economic performance in the EU is characterized by slow economic growth and long term employment (especially among the youth) and increasing income inequality. It is unlikely that Iceland will want to join during this current period of uncertainty.

\section{Conclusions}

The Icelandic economy is recovering from the 2008 global economic and financial crisis and, according to the IMF, is expected to surpass the pre-crisis GDP levels in 2015. According to the Central Bank of Iceland, this has already happened. The current economic growth is healthy and unemployment is low compared with high income EU countries. The economy is now better diversified than it was a decade ago. In terms of foreign exchange revenues it is based mainly on the three main pillars: (i) the traditional fisheries sector; (ii) aluminium production using domestic clean energy sources; and (iii) a flourishing tourism sector. Though challenges remain, including the removal of capital controls imposed during the crisis and salary increases that could result in inflation above the Central bank of Iceland inflation target.

After the 2008 crisis there was certain loss in confidence in the Icelandic institutional systems leading to the EU application submitted by the government in July 2009. One can argue that this included the recognition that Iceland needs to be shielded by stronger, more competent and less corrupt institutions and that EU membership could provide that shield and increase professionalism.

The sharp depreciation of the domestic currency, króna, during the crisis and its historic fluctuations and loss of value over the decades due to monetary mismanagement also called for the adoption of a new currency where the euro would be the most likely option. However, euro adoption would require EU membership and a two year period demonstrating sound economic management according to the EU criteria. While unilateral adoption of the euro is possible in theory, it seems unrealistic politically and is strongly opposed by the EU. Furthermore, a common currency would have limited Iceland's possibilities to respond to the 2008

settlement of disputes between two or more EEA EFTA States. It hears appeals against decisions taken by ESA and gives advisory opinions to courts in the EEA EFTA States on the interpretation of EEA rules (EFTA, 2014). 
crisis when depreciation of the króna played an important role in bringing about the adjustment of Iceland's trade deficit.

The so-called Icesave dispute with the UK and the Netherlands appears to have had damaging effect on how Icelanders view the European Union. The perceived EU backing of claims from the UK and the Netherlands has changed the way Icelanders view the EU and the European countries, thus public support for the EU membership is low in the post crisis. The government that took office in May 2013 has withdrawn the EU application and informed the EU that Iceland should no longer be considered an EU candidate country. After all national support for the EU accession remains low according to the recent public opinion polls.

Low economic growth, high unemployment and dysfunctional EU institutional systems, including the vulnerable euro also makes the EU less attractive. There are also issues related to cohesion and stability within the EU with the southern Europe performing poorly compared to the northern Europe.

The chapters on agriculture and fisheries policy were not opened during the EU accession negotiations, thus the most challenging for Iceland issues, related to the accession, were not even discussed and it remains unknown if the acceptable solution can be found and how it would look like.

Obviously, Iceland benefits from the access to the EU common market via the EEA agreement, enjoying gains from trade and economies of scale. This is possible as long as the EU is willing to respect the EEA agreement and as long as Norway is part in the EEA agreement. However, without Norway, Iceland would not have an institutional capacity to cooperate with the EU under the agreement and given the small size of Iceland and Lichtenstein it is doubtful if the EU would be interested in such cooperation.

Surely, should Iceland become a member of the EU, the union would only give a small weight to Iceland in its decision making given its small population and economic size. This would also apply to the ECB if Iceland eventually became a member of the Euro Area. According to Keohane's theory, Iceland as an EU member would fall under "system-ineffectual states" category, i.e., those states that can do little to influence the system-wide forces that affect them, except in groups which are so large that each state has minimal influence. Iceland could strive to become a "system-affecting state", i.e., among those states that cannot affect the international system if acting alone, but could exert some impact on the system by working through small groups or alliances. Cooperation with likeminded nations, especially the Scandinavian countries and to some extent the Baltic States, could be an option to consider. These countries, for example, cooperate within the World Bank, the IMF and the EBRD (e.g., Hilmarsson, 2011). However, experience shows that during times of crisis Iceland cannot rely on support from these small states that are more likely to follow their own interest or that of larger and more powerful EU member states. This became clear during the 2008 crisis when the Nordic countries also did not support Iceland strongly during the fisheries disputes with the UK.

Iceland has always been reluctant to participate in international organizations unless benefits from such participation are clear, such as in NATO that also involved a bilateral defence agreement with the USA with both security and economic benefits attached. Unlike the other Nordic countries the government has not build strong capacity to cooperate with international organizations and has preferred less formal structures and lower level of economic and political integration by being a member of EFTA and the EEA agreement.

One can argue that a small country like Iceland needs a shield in post crisis when it no longer benefits from strong bilateral relations with the USA, a system-determining country. History shows that Iceland preferred to use bilateral relations in solving its problems in the past and during crisis sometimes makes unilateral moves. In crisis situations Iceland has not hesitated to take actions against larger nations or group of nations, including the so called Cod Wars and the 2008 global crisis. These unilateral actions have been successful. This contradicts the small states literature, which generally claims that it is beneficial for small states to concentrate on multilateral relations within international organizations. The Icesave dispute also shows that the EU shield can have a high cost when the EU supports the claim of larger EU nations like during the Icesave dispute. Furthermore, the experience of Latvia and Ireland during the 2008 crisis further confirms that the EU shield can come at a high cost.

The question about the most feasible arrangement for Iceland's prosperity in the long term still remains? Partly this depends on whether the access to the common market remains via the EEA agreement. The slow 
growth, high unemployment and the ongoing crisis in some EU member states do not make EU membership attractive at least in the short term. Joining the Euro area would hardly be feasible unilaterally and adoption of the euro would be unlikely to take place until about two years after the EU accession.

EFTA membership and the EEA agreement appear to be the best arrangement for Iceland at present. The EEA agreement decision shaping under the two-pillar structure of the EEA EFTA bodies that match those on the EU side has so far served well. The three EEA countries have some modest influence under this system and this arrangement ensures access to the internal EU market. This can change in the medium or long-term and the decision made by the government of Iceland that Iceland should not be considered a candidate or potential EU candidate country was unwise. Iceland should not burn any bridges given how quickly the global environment can change.

\section{References}

Buiter, W. H. (2000). Is Iceland an Optimal Currency Area? Central Bank of Iceland. Working Paper, No. 10. Available at: http://www.sedlabanki.is/uploads/files/wp_10.pdf [Accessed on April 28, 2016].

Central Bank of Iceland, CIB. (2015). Monetary Bulletin, Vol. 17, No. 2, 13 May. Available at: http://www.cb.is/ publications/publications/publication/2015/05/14/May-2015/ [Accessed on May 26, 2016].

Central Bank of Iceland, CIB. (2014). Economy of Iceland. Available at: http://www.cb.is/publications-news-andspeeches/news-and-speeches/news/2014/09/19/Economy-of-Iceland-2014/ [Accessed on May 26, 2016].

Czinkota, M. R., Ronkainen, I. A., Moffett, M. H., Marinova, S., Marionv, M. (2009). International Business. European Edition. John Wiley \& Sons, Ltd. England.

Dinh, T. Q., Hilmarsson H. P. (2012). Private Sector Export to Emerging Market Economies During Times of Crisis: How Can Export Credit Agencies Help? Review of International Comparative Management, Vol. 13, Issue 1, March, p. 167-180.

European Central Bank, ECB. (2012). Recent Economic and Financial Developments in EU Candidate Countries. ECB Monthly Bulletin November 2012. Available at: https://www.ecb.europa.eu/pub/pdf/other/art2_mb201211en_ pp87-104en.pdf) ECB [Accessed on April 18, 2016].

European Central Bank, ECB. (2008). The adoption of the euro: principles, procedures and criteria Speech by Jürgen Stark, Member of the Executive Board of the ECB delivered at the Icelandic Chamber of Commerce Reykjavik, 13 February 2008. Available at: https://www.ecb.europa.eu/press/key/date/2008/html/sp080213.en.html [Accessed on April 18, 2016].

EFTA. (2014). This is EFTA. Available at: http://www.efta.int/sites/default/files/publications/this-is-efta/this-isefta-2014.pdf [Accessed on March 5, 2016].

Evans, G., Newnham, J. (1998). The Penguin Dictionary of International Relations. London: Penguin Books.

Hilmarsson, H. P. (2014). Small States in a Global Economy - Crisis, Cooperation and Contributions. Series on Economic Issues, Problems and Perspectives. Nova Science Publishers, Inc.

Hilmarsson, H. P. (2013a). The Banking Crisis in Iceland: Did the Government Pretend that Facts from Reality were Other than they Were? In T. Vissak, M. Vadi (eds.). (Dis)Honesty in Management. Advanced Series in Management, Vol. 10. Emerald Group Publishing Limited, p. 61-84. DOI:10.1108/S1877-6361(2013)0000010008

Hilmarsson, H. P. (2013b). Small states and big banks - the case of Iceland. Baltic Journal of Economics - Taylor \& Francis Routledge, Vol. 13(1), p. 31-48.

Hilmarsson, H. (2011). How can the Baltic States as Non-DAC donors best contribute to international development cooperation? Baltic Journal of Economics - Taylor \& Francis Routledge, Vol. (2), p. 27-40.

Hoadley, J. S. (1980). Small states as aid donors. International Organizations, Vol. 31, 1, Winter, p. 121-137. Available at: http://www.jstor.org/stable/2706619 [Accessed on April 1, 2016].

IMF. (2015a). IMF Executive Board Concludes 2014 Article IV Consultation and Fifth Post-Program Monitoring Discussion with Iceland. Available at: http://www.imf.org/external/np/sec/pr/2015/pr15114.htm [Accessed on May 2, 2016].

IMF. (2015b). Iceland: 2014 Article IV Consultation and Fifth Post-Program Monitoring

Discussions-Staff Report; Press Release; and Statement by the Executive Director for Iceland. Available at: http://www. imf.org/external/pubs/cat/longres.aspx?sk=42782.0 [Accessed on May 3, 2015].

IMF. (2012). Iceland: Staff Report for the 2012 Article IV Consultation and First Post-Program Monitoring Discussion. Available at: http://www.imf.org/external/pubs/cat/longres.aspx?sk=25853.0 [Accessed on May 3, 2016]. 
IMF. (2010). Iceland: 2010 Article IV Consultation and Third Review under Stand-By Arrangement and Request for Modification of Performance Criteria-Staff Report; Staff Supplement; Public Information Notice and Press Release on the Executive Board Discussion; and Statement by the Executive Director for Iceland. Available at: http://www.imf.org/external/pubs/cat/longres.aspx?sk=24256.0 [Accessed on May 3, 2016].

IMF. (2008). Iceland: Financial system stability assessment - Update. Available at: http://www.imf.org/external/pubs/ $\mathrm{ft} / \mathrm{scr} / 2008 / \mathrm{cr} 08368$.pdf [Accessed on May 3, 2016].

Ingebritsen, C. (2006). Scandinavia in world politics. Rowman \& Littlefield Publishers.

Institute of Economic Studies at the University of Iceland. (2014). Status of the accession negotiation between Iceland and the EU. Available at: http://www.mfa.is/status-of-the-accession-negotiations-between-iceland-and-the-eu/ [Accessed on April 29, 2016].

Kahler, M. (1992). Multilateralism with small and large numbers. International Organizations, Vol. 46, No. 3, p. 681708. Available at: http://www.jstor.org/stable/2706992 [Accessed on April 1, 2015].

Keohane, R. O. (1969). Lilliputians’ Dilemmas: Small States in International Politics. International Organizations, Vol. 23, No. 2, p. 291-310.

Maass, M. (2009). The elusive definition of the small state. International politics, Vol. 46(1), 65-83. Available at: http:// www.palgrave-journals.com/ip/journal/v46/n1/abs/ip200837a.html [Accessed on April 2, 2016].

Magnusson, G. (2010). Iceland and the importance of becoming a member of the EU family. Available at: http://www. atvinnuvegaraduneyti.is/radherra/raedurGM/nr/2826 [Accessed on March 5, 2016].

Ministry for Foreign Affairs. (2015). Letter from the Minister for Foreign Affairs to the European Commission. Available at: http://www.mfa.is/media/gunnar-bragi/Bref-ESB-ENS-pdf.pdf [Accessed on April 27, 2016].

Ministry for Foreign Affairs. (2013). Iceland welcomes acquittal in Icesave case. Available at: http://www.mfa.is/newsand-publications/nr/7515 [Accessed on April 29, 2016].

Thorhallsson, B., Rebhan, C. (2011). Iceland's Crash and Integration Takeoff: An End to European Union Scepticism? Scandinavian Political Studies, Vol. 34, No. 1, p. 53-73. Available at: http://onlinelibrary.wiley.com/doi/10.1111/ j.1467-9477.2010.00261.x/abstract [Accessed on April 6, 2016].

Thorhallsson, B. (2005). What features determine small states' activities in the international arena? Iceland's approach to foreign relations until the mid-1990s. Stjórnmál og stjórnsýsla - Veftímarit, Stofnun stjórnmála og stjórnsýslu, Háskóli Íslands, Vol. 1: 1, p. 107-140. Available at: http://www.irpa.is/article/view/861/pdf_4 [Accessed on May 6, 2016].

Yin, R. K. (2009). Case Study Research. Design and Methods. 4th ed. Vol. 5. California: SAGE Inc.

\section{AR ISLANDIJA TURĖTU STOTI İ EUROPOS SĄJUNGĄ IR PRISIJUNGTI PRIE EURO ZONOS?}

HiLMar Pór Hilmarsson

Akureyri universitetas (Islandija)

\section{Santrauka}

Islandija yra maža, bet daug išteklių turinti Europos šalis, labai priklausoma nuo užsienio prekybos. Remiantis Pasaulio Banko klasifikacijomis, nors Islandijoje yra tik 300 tūkstančių šalies gyventojų, šios šalies finansinès institucijos daro įtaką . Islandija yra mažiausia šalis tarptautinio ekonominio bendradarbiavimo ir plètros organizacijoje (OECD). Islandija labai priklausoma nuo prekybos su užsieniu, ypač Europos Sajunga, kur ekonominè ir politinè integracija stiprejja. Todèl klausimas, koks tolesnis bendradarbiavimo būdas yra geriausias Islandijai, tampa vis svarbesnis.

Islandija priklauso Europos laisvosios prekybos asociacijai (ELPA), Europos ekonominei zonai (EEA) ir iki šiol buvo Šengeno zonos bei Europos Sajungos kandidatè, kai valdžia nusprendè pasitraukti iš ES narystės derybų. Priklausymas Europos ekonominei zonai garantuoja Islandijos prieigą prie ES rinkos. Vis dèlto klausimas, koks tolesnis kelias naudingesnis Islandijai, išlieka. Islandija turètų toliau būti priklausoma 
nuo dabartinio sutarimo ar siekti narystės ES ir galbūt netgi tapti euro zonos dalimi? Kokie galimi pliusai ir minusai stojant ị ES ir prisijungiant prie Euro zonos?

Galima teigti, kad tokiai mažai valstybei kaip Islandija reikia apsaugos pokriziniu laikotarpiu, kai santykiai su JAV, sistemą nulemiančia šalimi, nebėra tokie naudingi. Istorija rodo, kad Islandija dažnai būdavo linkusi naudotis abipusę naudą teikiančiais sprendimais, bet krizès laikotarpiu priimdavo ir vienpusiškus sprendimus, priešingus didesnių valstybių ar jų grupių interesams. Pavyzdžiui, vadinamuoju „Menkių karo“ ar 2008 metų finansinès krizès laikotarpiais. Šiais atvejais tokie sprendimai šaliai buvo naudingi. Tačiau tie rezultatai neatitinka pasaulinių mažų valstybių gyvavimo pavyzdžių, dažniausiai teigiančių, kad smulkios valstybės turètų rūpintis internacionaliniais santykiais internacionalinių organizacijų dèka. „Icesave“ nesutarimas (išsaugoti Islandiją) taip pat atskleidžia, kad ES „,skydas“ gali labai daug kainuoti, ES labiau orientuojantis ị didesnių valstybių interesus. Latvijos ir Airijos patirtys 2008 metų globalios finansinès krizès laikotarpiu rodo, kad ES ,skydas“ gali būti per brangus.

PAGRINDINIAI ŽODŽIAI: ekonomine integracija, mažos valstybès, Islandija, globali krizè, ekonominè politika.

JEL KLASIFIKACIJA: F15, H12, E6 